\title{
Discovering the roles of subsurface microorganisms: Progress and future of deep biosphere investigation
}

\author{
WANG FengPing ${ }^{1,2^{*}}$, LU ShuLin ${ }^{1}$, ORCUTT Beth $\mathrm{N}^{3,4}$, XIE Wei $^{5}$, CHEN Ying ${ }^{1,2}$, \\ XIAO Xiang ${ }^{1} \&$ EDWARDS Katrina $\mathbf{J}^{6^{*}}$ \\ ${ }^{1}$ State Key Laboratory of Microbial Metabolism and State Key Laboratory of Ocean Engineering, Shanghai Jiao Tong University, \\ Shanghai 200240, China; \\ ${ }^{2}$ Key Laboratory of Systems Biomedicine, Ministry of Education, Shanghai Jiao Tong University, Shanghai 200240, China; \\ ${ }^{3}$ Center for Geomicrobiology, Aarhus University, Aarhus C, DK-8000, Denmark; \\ ${ }^{4}$ Bigelow Laboratory for Ocean Sciences, 60 Bigelow Drive, East Boothbay, ME 04544, USA; \\ ${ }^{5}$ School of Ocean and Earth Sciences, Tongji University, Shanghai 200092, China; \\ ${ }^{6}$ The University of Southern California, Departments of Biological \& Earth Sciences, Los Angeles, CA 90089, USA
}

Received March 15, 2012; accepted June 8, 2012; published online August 16, 2012

\begin{abstract}
The discovery of the marine "deep biosphere"-microorganisms living deep below the seafloor-is one of the most significant and exciting discoveries since the ocean drilling program began more than 40 years ago. Study of the deep biosphere has become a research frontier and a hot spot both for geological and biological sciences. Here, we introduce the history of the discovery of the deep biosphere, and then we describe the types of environments for life below the seafloor, the energy sources for the living creatures, the diversity of organisms within the deep biosphere, and the new tools and technologies used in this research field. We will highlight several recently completed Integrated Ocean Drilling Program Expeditions, which targeted the subseafloor deep biosphere within the crust and sediments. Finally, future research directions and challenges of deep biosphere investigation towards uncovering the roles of subsurface microorganisms will be briefly addressed.
\end{abstract}

deep biosphere, ocean drilling, habitats, niche, dark energy, CORK history of the discovery of the marine deep biosphere

Citation: Wang F P, Lu S L, Orcutt B N, et al. Discovering the roles of subsurface microorganisms: Progress and future of deep biosphere investigation. Chin Sci Bull, 2013, 58: 456-467, doi: 10.1007/s11434-012-5358-x

The exploration of life in the dark sea floor can be traced back to the 1930s, when Claude Zobell from Scripps Institute of Oceanography found bacteria in the surface layers of deep-sea sediment cores within the range of centimeters to a few meters [1], and that triggered speculation on the energy generating processes that could support this subsurface biosphere [2,3]. In 1977, deep-sea hydrothermal vents and the supported ecological system surrounding them were first discovered by the manned submersible Alvin (Woods Hole Oceanographic Institution) around the Galapagos MidOcean Ridge (MOR) [4]. In 1994, Parkes et al. [5] were the first to describe microorganisms existing in deep sea sedi-

*Corresponding authors (email: fengpingw@sjtu.edu.cn; kje@usc.edu) ment cores obtained during the Ocean Drilling Program, down to several hundreds of meters below sea floor (mbsf). These early occasional, opportunistic explorations motivated a more coordinated, systematic investigation of this subsurface biosphere, revealing a huge habitat of life that had been "hidden" in the interior of the Earth. Unlike the "light" biosphere, which is supported by the sunlight energy at the surface of the Earth, the deep biosphere is in the dark, separated from sunlight energy, so most of the energy for life comes from chemical reactions. The discovery and exploration of the subsurface biosphere, largely reliant upon the international Integrated Ocean Drilling Program (IODP), is regarded as one of the most exciting research frontiers in both the Geology and Biology disciplines, and the last decade 
has produced a tremendous increase in deep biosphere studies around the world. For example, within the USA, the Center for Dark Energy Biosphere Investigation (C-DEBI), a Science and Technology Center supported by the United States National Science Foundation, has attracted worldwide researchers, becoming an incubator for active international collaborations.

Although deep biosphere exploration is still in its initial stage, it becomes a focus for both the scientific community and a concern from governments and public society due to its potential great impacts:

The deep biosphere buried in sediments may be the largest potential ecosystem on Earth-it is estimated to harbor one tenth to one third of all biomass, and two-thirds of all microbial biomass on Earth [5,6]. These early calculations focused on sediments at the bottom of the ocean, and the size of the reservoir of life harbored in oceanic crust is unknown.

The sediment deep biosphere is a huge carbon reservoir of between 56 and 303 petagram of carbon, equivalent to that of all plant life on Earth [6,7]. It may also be an enormous reservoir of nutrients, as prokaryotes typically contain tenfold more phosphorus and nitrogen by mass than plants [6].

The deep biosphere is not isolated-it has intimate connection with water cycles, with enormous potential for influencing global-scale biogeochemical processes, including carbon and nutrient cycles, energy fluxes, and climate [8,9].

The ramifications of a massive buried biosphere within the Earth are significant, leading to paradigm shifts in our thinking in both biosciences and geosciences [8,9]. Study of life in the deep subseafloor environments is technologically and analytically the most challenging in the Earth and Life sciences. Accessing samples requires scientific drilling ships (like those used in the oil industry), which are currently only available through the international scientific ocean drilling program. For the first time in the history of the ocean drilling programs, following on the success of ODP Leg 201 dedicated to studying the sediment deep biosphere [9], study of the deep biosphere and subsurface ocean became a central theme within the IODP science plan. Deep biosphere research matured from previous isolated opportunistic exploration into coordinated, targeted investigation. Microbiologists are now encouraged to sail on all IODP expeditions, and three deep-biosphere focused IODP expeditions have just taken placed within the past two years: Expedition 331 to study the Deep Hot Biosphere in sediments of the Okinawa Trough [10], Expedition 329 to study the most energy starved sediments underlying the South Pacific Gyre [11], and Expedition 336 to study the deep biosphere hosted in oceanic crust on the Mid-Atlantic Ridge flank [12]. It is anticipated that the on-going data analysis and experimentation based on these recent expeditions will bring us new insights, or perhaps even revolutionize our present knowledge on the subseafloor biosphere.

Below, we will use the recently operated Mid-Atlantic Ridge Flank Deep Biosphere IODP Expedition 336 [12] as an example to introduce basic knowledge, recent progress and accomplishments in deep biosphere research, and to highlight future directions, opportunities and challenges in this young field. For more detailed discussion of the deep biosphere, the reader is referred to several recent reviews [13-17].

\section{Background}

The ocean covers around $70 \%$ of the earth surface, and it represents the largest water mass on Earth and the largest aqueous habitat for microbial life. Beneath the ocean water column, massive and various types of environments such as marine sediments, oceanic crust, hydrothermal vents, cold seeps exist (Figure 1) and comprise the largest volume of habitats that life — in particular microbial life — can occupy on Earth [15]. The subseafloor harbors two general types of materials: sediments (derived from both terrigenous and oceanic materials) and igneous rocks and their (partially) altered products such as sulfides and carbonates. The estimated total volume of sediments including shelf, slope, rise, abyssal sediments is around $4.5 \times 10^{17} \mathrm{~m}^{3}, \sim 30 \%$ of the total ocean water volume; while the estimated ocean crust volume is twofold the volume of sea water [18]. Within the igneous oceanic crust, typically the upper $\sim 500 \mathrm{~m}$ is porous and permeable to fluids, and it hosts the largest aquifer system on Earth which is about $2 \%$ of the ocean water volume [19]. Moreover, most (at least 60\%) of the oceanic crust is hydrologically active - the fluids in the oceanic crust are exchanged mainly near mid-ocean ridges and on the ridge flanks with the overlying oceans through hydrothermal circulation [20,21]. The volume-equivalent of the entire ocean water is circled through this crustal aquifer every 200000 years [19]. While detailed background on all of the different subsurface habitats has been reviewed elsewhere [13,15], we focus on the major characteristics of the two subseafloor provinces-marine sediment and igneous ocean crust-with more emphasis on describing the latter for the readers to better understand why the Mid-Atlantic Ridge flank was chosen as an important study site and as a research frontier for deep biosphere investigation.

\subsection{Subseafloor habitats}

(i) Marine sediment provinces. Marine sediments are formed by accumulation of particles that sink to the seafloor from the overlying sea water, and they cover nearly the entire sea floor in a range of a few centimeters near the newly formed oceanic crust to $\mathrm{km}$ thick blankets in continental margin and abyssal trenches [17]. The reactions and chemical transport in marine sediments are predominantly controlled by diffusion, although advective transports of chemical compounds also occur at sites where fluids move actively, such as at methane gas seeps and mud volcanoes. 


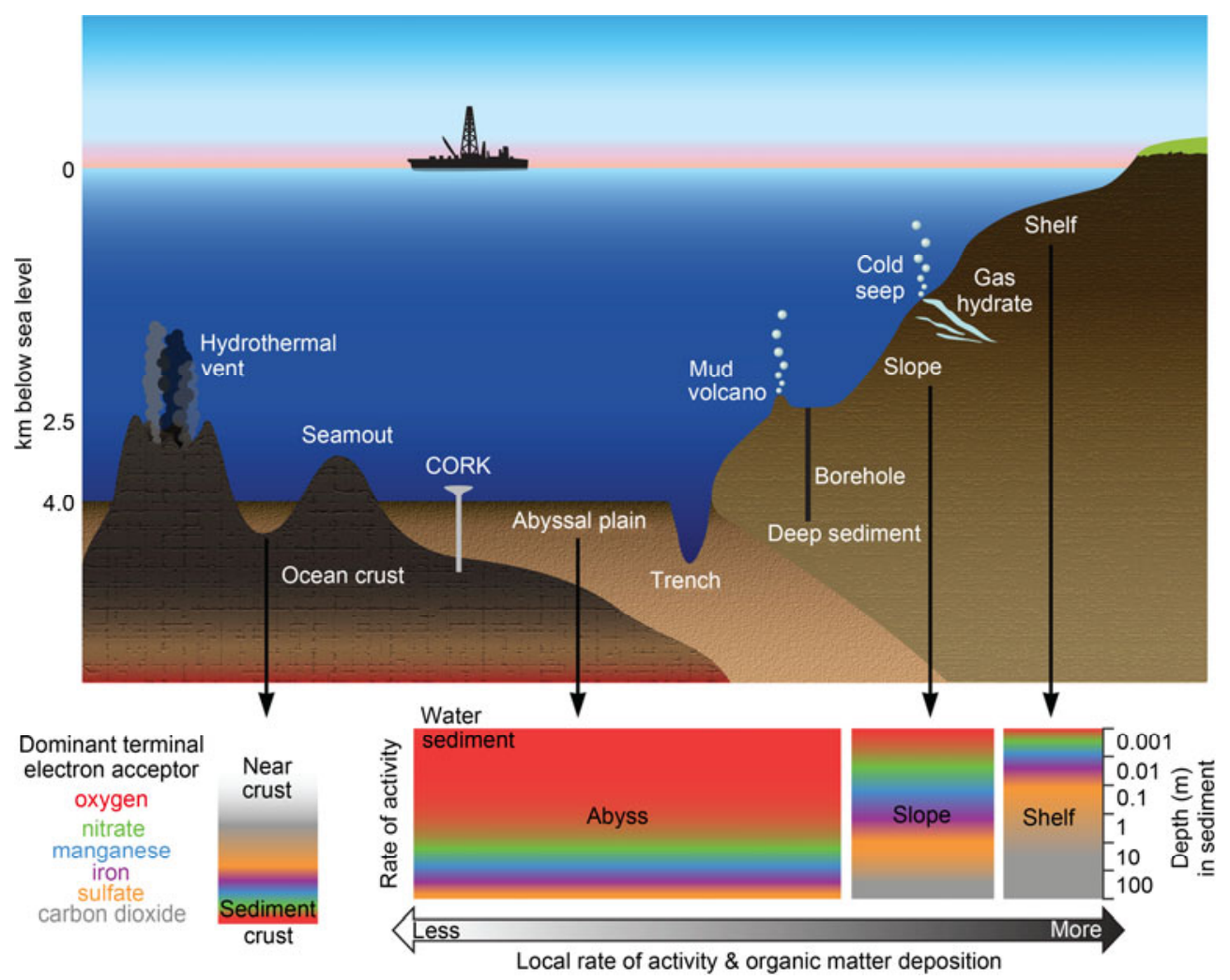

Figure 1 A schematic overview of dark ocean habitats (top) and representations of sediment biogeochemical zonation (bottom), originally published in [13] and presented here with permission. In the lower panel, dominant electron acceptors in the various sediment habitats are indicated by vertical depth into sediment. For more details please read ref. [13].

According to their distance to a tectonic plate or land boundary, marine sediments can be generally classified as active continental margin, passive continental shelves and slopes, and abyssal plains [13]. Our current knowledge of the subseafloor biosphere is mainly obtained from sediments which are shallow $(<1 \mathrm{~m})$ and from organic-rich continental margin sites, as these are the easiest to access and collect [15]. Almost all sites where subseafloor sedimentary life has been studied are on ocean margins (Ocean Drilling Program [ODP] Legs 112, 180, 201, and 204 and Integrated Ocean Drilling Program [IODP] Expeditions 301, 307, and 323 ) or in the equatorial ocean (ODP Legs 138 and 201). While the abyssal plains account for $\sim 80 \%$ of the seafloor worldwide and are generally carbon and nutrient poor oligotrophic open ocean areas with depths greater than $4000 \mathrm{~m}$, they are generally poorly investigated. Several recent cruises and expeditions to these oligotrophic ocean gyre areas, including IODP Expedition 329 to the South Pacific Gyre and Expedition 336 to the North Atlantic, are poised to provide greatly needed information about the composition and activity of the deep biosphere in these open ocean provinces $[11,12]$. Expedition 329 prioritized collection of sediments, for understanding the carbon-starved subseafloor sedimentary biosphere, although some basement materials were also collected [11]. Available data from the South Pacific Gyre, collected during previous cruises, have already shown that the sediment of this region contains the lowest cell concentrations and lowest rates of microbial activity ever encountered in shallow marine sediment [22]. At all sites located within the gyre, microbial cell counts are three or more orders of magnitude lower than at the same sediment depths at all sites previously cored by scientific ocean drilling [22]. In contrast, Expedition 336 focused more on the subseafloor crust biosphere and setting up long-term subseafloor observatories for experimentation (see section below) [12]. Although the Mid-Atlantic Ridge expedition focused on the crust, complete sediment columns from the seafloor to the basement interface were also collected. Comparing and integrating the data from these two expeditions, and data from previous expeditions, will help us to understand the following key questions:

The subseafloor sedimentary biomass has been estimated to comprise one-tenth to one-third of total carbon of living biomass on Earth [5-7]. How accurate are these estimates? And what is the size of the microbial biome hosted in oceanic crust?

Are the microbial communities in the low-activity openocean gyres similar or different between each other and with those in the high-activity continental margins?

How do oceanographic factors control variation in microbial activities and biomass in subseafloor sediments?

What are the principal sources of metabolic energy in the 
oligotrophic open-ocean sedimentary and crustal habitats?

(ii) Igneous ocean crust provinces. Oceanic crust contains an estimated rock volume around 6-10 times that of the total marine sediments [13]. New oceanic crust is generated by interaction of Earth's magma with the lithosphere along mid-ocean ridges, which span $60000 \mathrm{~km}$ throughout the world's oceans. Globally, new oceanic crust of $21 \mathrm{~km}^{3}$ is generated on the sea floor annually, and the ocean crust is recycled on average of 61 million years $[23,24]$. The oceanic crust is generally described as three layers: the upper layer of $\sim 500 \mathrm{~m}$ thick, composed of fractured and permeable basalts; a middle layer of a few hundred meters thickness of sheeted dikes, which are essentially the crystallized igneous conduits for magma transfer; and the deeper layer is comprised of mantle-type rocks like gabbros, extending down to roughly $4 \mathrm{~km}$ in depth. The upper $\sim 500 \mathrm{~m}$ of subseafloor basalt host significant porosity and permeability, harboring the largest hydrologically active aquifer on Earth, and is thus regarded as the largest potential microbial habitat on Earth $[20,25]$. Subseafloor rock provinces can be divided into various types, according to their location and geochemicalphysical characteristics, such as Mid-Ocean Ridges (MOR), Ridge Flanks, Island Arc Environments, and Oceanic Island Volcanoes, as described in the previous reviews [15]. Here we will focus on the two most typical environments: MOR and Ridge Flanks, as they occupy the largest area on the sea floor.

Mid-Ocean Ridges. Along the $600000 \mathrm{~km}^{2}$ MOR in the global ocean floor, outcropping of heated crust fluids is nearly continuous and abundant $[8,19,21]$. The high temperature fluids interact with igneous rocks, creating highly reduced, metal-rich fluids, chemically distinct from the surrounding seawater. The chemical compositions of the hydrothermal fluids vary, and the disequilibrium between the reduced hot fluids and the cold seawater may result in mineral precipitation to form mineral deposits such as hydrothermal chimneys and mounds. According to the spreading rates of the oceanic plates, three primary types of mid-ocean ridges (MOR) are classified: fast spreading ridges which include the East Pacific Rise and the Central Indian Ridge; slow and ultra-slow spreading ridges such as the Mid-Atlantic Ridge, Gakkel Ridge, and Southwestern Indian Ridge; and the intermediate-spreading ridges such as Jude de Fuca Ridge in the eastern Pacific. Generally, most hydrothermal venting occurs at areas with low sediment cover on young oceanic crust, but venting in sediment-covered settings is also observed in places such as Guaymas Basin in the Gulf of California, and Middle Valley on the landward eastern flank of Juan de Fuca Ridge. At MOR settings, the subseafloor environments are hot, chemically reduced from the interaction of circulating sea water with surrounding igneous rocks at elevated temperature and pressures, and dynamic due to perpetual renewal by volcanic eruptions and associated earthquake activity [15].

The venting fluids and the formed metal deposits which are cooled by cold seawater are ideal habitats for microorganisms. These microorganisms could use the rich amounts of volatiles and reduced compounds which are created by the chemical reactions as energy sources for growth, thus serving as the food source and base of the chemosyntheticfueled vent ecosystem seen at vents [26]. The highly divergent and dynamic chemical natures of the MORs support a great diversity of Bacteria and Archaea, varying and evolving from vents to vents, within a single vent across the chemical and/or temperature gradients, and during different growth stage of a vent [27-29]. Recent studies demonstrated that the biogeographic patterns of hydrothermal vent microorganisms are shaped primarily by large variations of geochemical compositions of hydrothermal fluids, particularly the $\mathrm{H}_{2}$ concentrations [30]. These hydrothermally-driven water-rock reactions are a fundamental component of global geochemical cycles and are critical for understanding exchanges and fluxes between the crust and the oceans.

The direct sampling of igneous rocks in MORs is technically challenging due to high temperature and low or no sediment cover, which is required by present drilling technology. The current most feasible "access" to the subseafloor habitats beneath these hydrothermal systems is through direct sampling of natural diffusive springs. A variety of investigations therein provided indirect data suggesting the existence of a subvent hot biosphere supported by energy primarily from degassing of volatiles and by hydrothermal water-rock reactions [31-34]. However, to gain direct proofs to test this hypothesis and quantify the extent of this subsurface hot biosphere would require drilling through the crust. The recent IODP Exp331 (9.1-10.4, 2010) drilled into the Iheya North hydrothermal field in the middle Okinawa Trough to investigate metabolically diverse subseafloor microbial ecosystems and their physical and chemical settings. However, investigations from Exp331 were not able to provide direct proof for the existence of a deep hot biosphere beneath the hydrothermal field, and more future drillings are expected and needed.

Ridge flanks. The ridge flank environment begins $\sim 5 \mathrm{~km}$ to hundreds of kilometers off the ridge axis, and extends to oceanic trenches as long as hydrothermal circulation is maintained [35]. Hydrothermal circulation at ridge flanks is driven by latent heating of the cool oceanic crust which is typically $<20^{\circ} \mathrm{C}$, and by pressure gradients caused by irregularities in crust and sediment topography [36]. Venting of warm fluids at ridge flanks occurs either through basalt crust, or also through uplifted ultramafic mantle rock. A unique hydrothermal field known as Lost City was found $15 \mathrm{~km}$ from the Mid Atlantic Ridge at the latitude of $30^{\circ} \mathrm{N}$, where the vent fluids are exposed to uplifted peridotites and serpentinized [37]. The venting fluids are high in $\mathrm{pH}$ (up to 12$)$, hot $\left(40-90^{\circ} \mathrm{C}\right)$, rich in hydrogen, methane, and small organic molecules-substantially different from black smoker hydrothermal fluids-which accordingly support a substantially distinct microbial ecosystem gaining energy 
mainly from methane and hydrogen [38,39]. More venting systems and associated ecosystems like Lost City are expected to be discovered because ultramafic rocks and serpentinization reactions are thought to occur commonly in the ocean floor.

Ridge flanks could be mainly divided as young ridge flanks $(<10 \mathrm{Ma})$ with variable temperature, and older, cooler flanks (>10-65 Ma) [15]. Glass alteration textures have been interpreted as evidence of microbial colonization in subseafloor basalt as old as $145 \mathrm{Ma}$ [25]; however, more evidence points out that the most reasonable place to search for active sub-surface microbial communities may be in young ridge flanks $(<10 \mathrm{Ma},[40,41])$. In cold young ridge flanks, chemical reaction kinetics are inhibited, thus reactions catalyzed by biological enzymes would have an advantage. Considering the vast size of the cold young ridge flank habitat, microorganisms may play important roles in promoting rock weathering and influencing global chemical budgets.

Most young ridge flanks lack sediment cover, which presents difficulty for intact recovery of upper-ocean crust. Expedition 336 targeted a site called "North Pond"-an isolated northeast-trending intermontaine sediment pond, approximately $8 \mathrm{~km} \times 15 \mathrm{~km}$ in aerial extent, and located on the western flank of the Mid-Atlantic Ridge. The basement age is suggested to be around $8 \mathrm{Ma}$ [42], and sediment thickness is around $50-300 \mathrm{~m}$. The studies at young and cool North Pond are expected to provide an excellent point of comparison for similar studies taking place both at the Juan de Fuca Ridge flank (targeted by IODP Expeditions 301 and 327 $[43,44])$ that targets warm young crust with anaerobic conditions. Similarly, the North Pond and Juan de Fuca Ridge flank studies of young oceanic crust will provide a useful contrast to the aged oceanic crust sampled during Expedition 329 to the South Pacific Gyre (crustal ages of $>100 \mathrm{Ma}$ ) and Expedition 330 to the Louisville Seamounts (crustal ages $>70 \mathrm{Ma}$ ). Comparisons of these investigations will document first-order patterns of basement habitability and potential microbial activities at a global scale [45].

\section{Microbiology of subseafloor habitats}

All forms of life from microorganisms to human beings need to make a living by exploiting well-defined energy and carbon sources. To understand what kinds of organisms inhabit an environment and their ecological functions, the first questions to ask are always: "What drives metabolism here?" Or in another way "What could serve as electron donor and electron acceptors to drive the metabolic reactions?" "What are the energy and carbon sources?" In the dark subsurface environments, in the absence of sunlight, which is the major energy source for the surface biosphere on Earth, organisms gain energy from the coupling of reducing and oxidizing ("redox") reactions which are ther- modynamically favorable and yield enough energy for ATP generation (Table 1). The metabolically usable electron donors in the deep biosphere include $\mathrm{H}_{2}, \mathrm{CH}_{4}$, organic matter, reduced sulfur compounds, reduced mineral compounds such as iron, manganese compounds, ammonium, and others. The electron acceptors may include oxygen, nitrate and nitrite, manganese and iron oxides, oxidized sulfur compounds such as sulfate, sulfite, and carbon dioxide. In the deep subsurface, the available electron donors and electron acceptors vary significantly in different habitats which could be the major driver of the microbial diversity, distribution or biogeography $[12,40,46]$. Also, there are other extreme conditions to consider in the subsurface such as high temperature (or low temperature) and high pressure, which would substantially set the limitation boundary for life to sustain - thus dictating the diversity and physiology of the microorganisms therein.

\subsection{Microorganisms in ocean sediment}

Microorganisms in deep subsurface sediments have been demonstrated to have extremely low activity with biomass turnover time of hundreds of thousands of years [47], which makes cultivation of some of these microorganisms tremendously difficult. Owing to the rapid development and progress of molecular techniques, our general understanding of microorganisms- particularly regarding microbial diversity and biogeography - has increased substantially during the last three decades. In the subsurface biosphere, most of our current knowledge comes from ocean sediments due to sample accessibility through ocean drilling projects. However, even in the relatively better-characterized marine sediment environments, which as pointed out previously are skewed to the shallow, oceanic marginal sediment environments, there are still many more issues to be addressed. In general, we tend to now know which microorganisms are in different types of sediments, however we do not understand why some groups are present and others not, and what all of the different microorganisms are doing.

As an example, the microorganisms involved in sedimentary methane cycling have been a continued target of study for several decades, owing to the importance of sediments as a significant source of methane-a powerful greenhouse gas and an important source of energy; yet large uncertainty still exists about the types of microorganisms involved in methane-related processes. The production of methane in sediments is well studied, yet the microorganisms responsible for methane production are not clear, as known methanogenic microbes are rarely recovered in molecular investigations. Similarly, the microorganisms responsible for methane oxidation in sediments are also somewhat enigmatic. Results from copious studies document the existence of a few unique groups of Archaea in methane-rich sediments from around the world, although all attempts to cultivate these organisms have been unsuccessful. 
Table 1 Common chemical reactions and associated standard free energies for reactions in the subseafloor $[40,46]$

\begin{tabular}{|c|c|c|}
\hline Pathway & Reaction & Free energy $(\mathrm{kJ} / \mathrm{mol}$ reaction) \\
\hline \multicolumn{3}{|l|}{ Aerobic metabolism } \\
\hline Oxic respiration & $\mathrm{CH}_{2} \mathrm{O}+\mathrm{O}_{2} \rightarrow \mathrm{CO}_{2}+\mathrm{H}_{2} \mathrm{O}$ & 770 \\
\hline Hydrogen oxidation & $\mathrm{H}_{2}+1 / 2 \mathrm{O}_{2} \rightarrow \mathrm{H}_{2} \mathrm{O}$ & 263 \\
\hline Methane oxidation & $\mathrm{CH}_{4}+2 \mathrm{O}_{2} \rightarrow \mathrm{CO}_{2}+2 \mathrm{H}_{2} \mathrm{O}$ & 859 \\
\hline Sulfide oxidation & $\mathrm{H}_{2} \mathrm{~S}+2 \mathrm{O}_{2} \rightarrow \mathrm{SO}_{4}^{2-}+2 \mathrm{H}^{+}$ & 750 \\
\hline Iron oxidation & $\mathrm{Fe}^{2+}+1 / 4 \mathrm{O}_{2}+\mathrm{H}^{+} \rightarrow \mathrm{Fe}^{3+}+1 / 2 \mathrm{H}_{2} \mathrm{O}$ & 48 \\
\hline Manganese oxidation & $\mathrm{Mn}^{2+}+1 / 2 \mathrm{O}_{2}+\mathrm{H}_{2} \mathrm{O} \rightarrow \mathrm{MnO}_{2}+2 \mathrm{H}^{+}$ & 149 \\
\hline Aerobic nitrification & $\mathrm{NH}_{4}^{+}+2 \mathrm{O}_{2} \rightarrow \mathrm{NO}_{3}^{-}+2 \mathrm{H}^{+}+\mathrm{H}_{2} \mathrm{O}$ & 302 \\
\hline \multicolumn{3}{|l|}{ Anaerobic metabolism } \\
\hline Methanogenesis & $\mathrm{HCO}_{3}^{-}+\mathrm{H}^{+}+4 \mathrm{H}_{2} \rightarrow \mathrm{CH}_{4}+3 \mathrm{H}_{2} \mathrm{O}$ & 130 \\
\hline Anerobic methane oxidation & $\mathrm{CH}_{4}+\mathrm{SO}_{4}^{2-} \rightarrow \mathrm{HCO}_{3}^{-}+\mathrm{HS}^{-}+\mathrm{H}_{2} \mathrm{O}$ & 16 \\
\hline Sulfate reduction & $\mathrm{CH}_{2} \mathrm{O}+1 / 2 \mathrm{SO}_{4}^{2-} \rightarrow \mathrm{HCO}_{3}^{-}+1 / 2 \mathrm{H}_{2} \mathrm{~S}$ & 33 \\
\hline \multirow[t]{2}{*}{ Fermentation } & $\mathrm{CH}_{3} \mathrm{CH}_{2} \mathrm{OH}+\mathrm{H}_{2} \mathrm{O} \rightarrow \mathrm{CH}_{3} \mathrm{COOH}+2 \mathrm{H}_{2}$ & 181 \\
\hline & $\mathrm{CH}_{3} \mathrm{CH}_{2} \mathrm{OO}^{-}+3 \mathrm{H}_{2} \mathrm{O} \rightarrow \mathrm{CH}_{3} \mathrm{COOH}+\mathrm{HCO}_{3}^{-}+3 \mathrm{H}_{2}$ & 1075 \\
\hline Denitrification & $\mathrm{CH}_{2} \mathrm{O}+4 / 5 \mathrm{NO}_{3}^{-} \rightarrow 1 / 5 \mathrm{CO}_{2}+2 / 5 \mathrm{~N}_{2}+4 / 5 \mathrm{HCO}_{3}^{-}+3 / 5 \mathrm{H}_{2} \mathrm{O}$ & 463 \\
\hline Anaerobic iron oxidation & $\mathrm{Fe}^{2+}+1 / 5 \mathrm{NO}_{3}^{-}+6 / 5 \mathrm{H}^{+} \rightarrow \mathrm{Fe}^{3+}+1 / 10 \mathrm{~N}_{2}+3 / 5 \mathrm{H}_{2} \mathrm{O}$ & 44 \\
\hline Manganese oxide reduction & $\mathrm{CH}_{2} \mathrm{O}+3 \mathrm{CO}_{2}+\mathrm{H}_{2} \mathrm{O}+2 \mathrm{MnO}_{2} \rightarrow 2 \mathrm{Mn}^{2+}+4 \mathrm{HCO}_{3}^{-}$ & 557 \\
\hline Iron oxide reduction & $\mathrm{CH}_{2} \mathrm{O}+7 \mathrm{CO}_{2}+4 \mathrm{Fe}(\mathrm{OH})_{3} \rightarrow 4 \mathrm{Fe}^{2+}+8 \mathrm{HCO}_{3}^{-}+3 \mathrm{H}_{2} \mathrm{O}$ & 697 \\
\hline Anammox & $\mathrm{NH}_{4}^{+}+\mathrm{NO}_{2}^{-} \rightarrow \mathrm{N}_{2}+2 \mathrm{H}_{2} \mathrm{O}$ & 345 \\
\hline
\end{tabular}

Three separate groups of Archaea-the ANME-1, -2- and -3 groups, where ANME was proposed to stand for Anaerobic Methane oxidizers [48,49], are often observed in these sediments. ANME Archaea are closely related to known, cultivated methanogenic Archaea [50], yet they are often suggested to be methane-consuming organisms instead of methane producers. The common occurrence of sulfate reducing bacteria in association with ANME suggests that methane consumption is syntrophically coupled to sulfate reduction, although very little energy is available from this coupled process. However, there are several instances where ANME archaea are observed without syntrophic partners, and some researchers have suggested that ANME can actually be methanogenic [51]. In recent years, some ANME archaea were found to be capable of nitrogen fixation [52], and methane oxidation was observed to proceed coupled with iron and manganese reduction in marine sediments [53]. Clearly, there are still many unknowns about methane cycling in marine sediments despite decades of research.

Similarly, our knowledge of the biogeochemical roles of other microbial groups, especially those who have no close culture representatives, are nearly blank, although some of them are predicted to have big functions in the element cycling in nature $[13,15]$. For example, Uncultivated Miscel- laneous Crenarchaeota Group (MCG) is one of the most abundant groups in the subsurface sediment biosphere and was found widespread in various habitats, such as at ODP site 1227 on the Peru Margin, MCG Archaea were abundant in 16S rRNA gene clone libraries from all depths [54,55]. Carbon-isotopic signatures of archaeal cells and polar lipids from MCG-dominated sediment horizons indicated that MCG are anaerobes utilizing buried organic carbon substrates [54]. Metagenomic analysis found that MCG contain a functional bacteriochlorophyll a synthase $(b c h G)$ gene, a key enzyme for bacteriochlorophyll a biosynthesis. However, the in vivo physiological functions of BchG in MCG is still unknown, although it was supposed that containing a presumptive Bchl a synthase gene may give the archaea more flexibility to survive or adapt to various environments [56]. The exact carbon sources, the physiology and ecological roles of MCG remain obscure since no MCG laboratory isolate is available. In short, we are getting knowledge about the diversity of microorganisms in the marine sediments, however, it is even more challenging to link the diversity with the functioning, and with the geochemical roles of these microorganisms at a global scale. Some new stateof-the-art technologies, such as single cell-based molecular techniques discussed below, will be essential to address 
some of these unknowns.

\subsection{Microorganisms in ocean crust}

Comparing to marine sediments, the microbiology of the igneous ocean crust remains very poorly studied and little described. When considering the first question as "what drives the metabolic reactions?" in subseafloor crust, disequilibrium between the strongly reduced forms of $\mathrm{Fe}, \mathrm{S}, \mathrm{Mn}$, and other elements in the rock and relatively oxidized sea water containing oxidants such as $\mathrm{O}_{2}, \mathrm{NO}_{3}$, and $\mathrm{SO}_{4}$ could be catalyzed by organisms to gain metabolic energy (Table 1). In the low temperature ridge flanks, the redox reactions are sluggish without catalysis, microorganisms thus can take the advantages by catalyzing the reactions and gain energy [46]. Iron and sulfur oxidation are likely the most abundant sources for organisms to explore for energy, as they are abundant in the crust [40]. Another potential important energy source is hydrogen $\left(\mathrm{H}_{2}\right)$ which is generated by fluid-rock interactions, and are suggested as important factor to shape the microbial community in hydrothermal vents $[33,57]$.

A handful of studies of bacterial diversity in seafloorexposed and deeper basalts demonstrated high diversity, dominated by the phyla Proteobacteria (in particular, the classes Alphaproteobacteria and Gammaproteobacteria), Actinobacteria, Bacteriodetes, Chloroflexi, Firmicutes and Planctomycetes [13,18,58,59]. Based on these limited datasets, and in comparison with other deep sea habitats, some trends in bacterial biogeographic distributions were recently observed, where microbial community membership varied coherently between geologically, geochemically and physically distinct provinces (Figure 2). Some of the phylogenetic taxa seem to be unique to the subsurface [14]—for example the Firmicutes phyla_-although this apparent uniqueness is

(a)

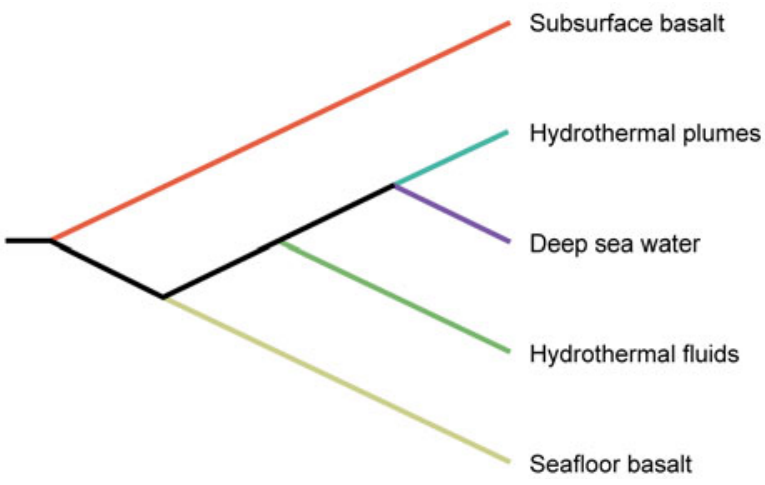

(b)

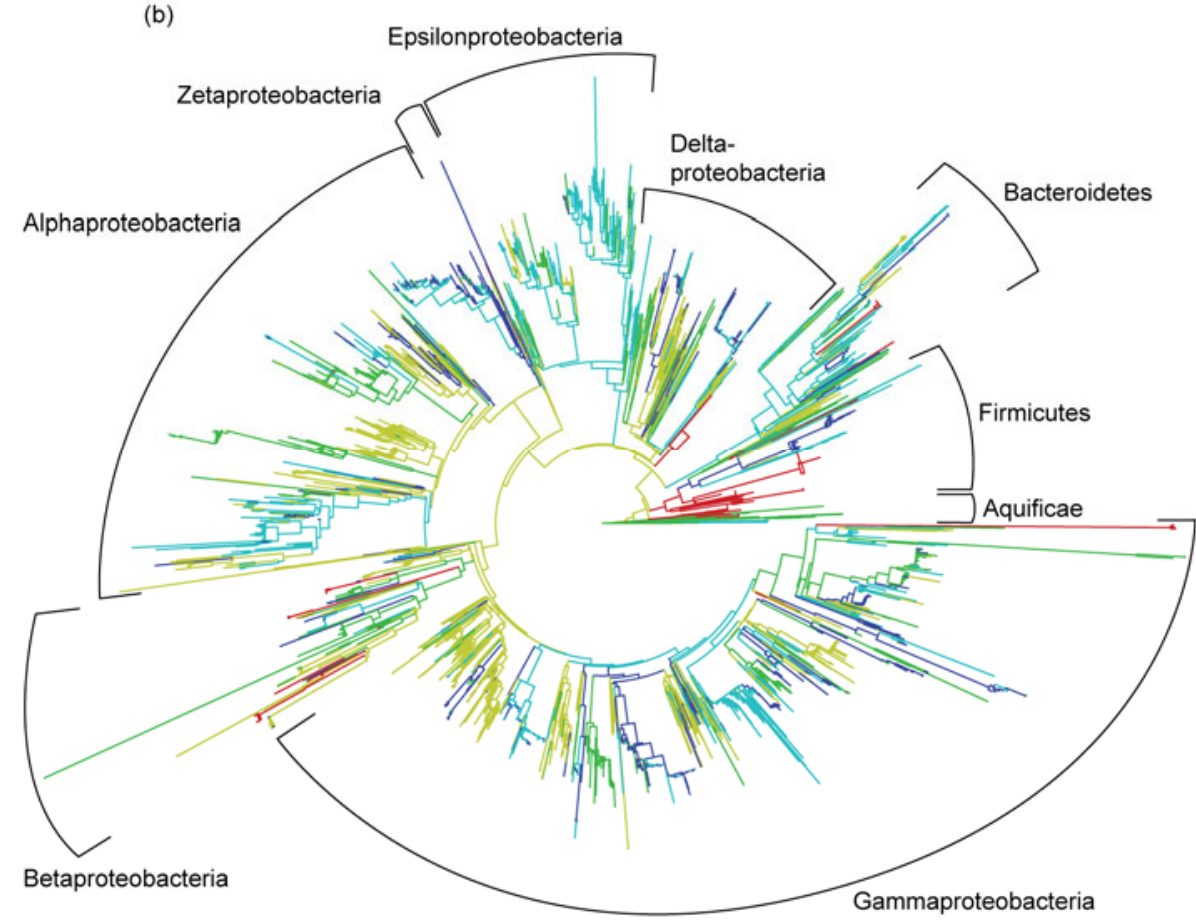

Figure 2 Bacterial community in different (sub-)sea floor habitats, demonstrating that subsurface crustal bacteria are distinct from the bacteria in other deep-sea environments. Figure originally published in [14] and presented here with permission. 
skewed to studies from two subsurface observatories at one hydrothermal study site [60]. Microorganisms involved in iron cycling (iron oxidation and reduction) have been identified in seafloor basalt samples, both by cultivation independent molecular analyses and cultivation approaches [61]. Iron-oxidizing Zetaproteobacteria were not only confirmed to be present, but also suggested to have active roles in seafloor basalt alteration [62]. Meanwhile, other bacterial groups such as some Alphaproteobacteria and Gammaproteobacteria were also suggested as putative iron oxidizers in the alteration of seafloor basalts [58]. The recent expeditions that recovered basalts from the Juan de Fuca Ridge flank (Expedition 327, [44]), the South Pacific Gyre (Expedition 329, [11]), the Louisville Seamounts (Expedition 330, [63]) and the Mid-Atlantic Ridge (Expedition 336, [12]) will soon provide more data on microorganisms in the ridge flank crusts, allowing one to address carefully and deeply the questions related with biogeography, endemism, genetics, and functioning of microorganisms in subsurface igneous habitats. All these efforts together will hopefully lead to constraints for microbial activity and diversity in the subsurface, and also the geochemical roles (such as carbon, iron and sulphur cycling) these bacteria play globally.

As to the archaeal populations in the crusts, generally low species diversity are found with the majority having no cultivated representatives $[18,58,59,64]$. On the other hand, highly diverse archaea and archaeal phylotypes are found in deep-sea hydrothermal vents, suggesting that deep-sea hydrothermal environments are the evolutionary and biogeographical origin of archaeal diversity on Earth [65]. Specific and/or indicator archaeal lineages to deep-sea hydrothermal environments are able to be identified [66]. Genetic analysis from metagenome comparisons also supported the uniqueness of the vent communities, by enriching of genes for mismatch repair, homologous recombination, and horizontal gene transfer [67].

\section{New tools and technologies}

\subsection{Under sea experimentation technologies}

The subseafloor scientific investigation is going through a phase of direct sample collection followed by laboratory investigation into (or combined with) a stage of in situ subseafloor observation and experimentation using newly developed tools and technologies. To avoid potential contaminations and perturbations associated with drilling, and more importantly to gain real-time data combining geophysical, geochemical, and biological processes below seafloor, CORKs (Circulation Obviation Retrofit Kits, [68]) are designed to stop bottom water influx, thus in situ borehole conditions can develop after drilling. CORKs were originally designed to allow for estimates of in situ flow rates and permeability; but they have been used for over a decade and evolve constantly to meet new demands from the scien- tific community and innovations in drilling technologies [69]. CORKs are now becoming important under water borehole laboratories for multidisciplinary scientific study, with hardware and experimental instrument packages used for temperature, pressure, seismic, chemical monitoring; crustal fluid sampling; and recently microbiological experiments [69]. More than 30 CORKs have been installed at a number of sites in the world ocean for different monitoring and experimenting purposes. The recently designed Flowthrough Osmo Colonization Systems (FLOCS) which consist of a series of cassettes containing various minerals and osmotic pumps to encourage in situ colonization and growth of subsurface microorganisms, have been deployed in the Juan de Fuca ridge flank CORKs during IODP Exp 327 [44], in the subsurface of the Nankai Trough during IODP Exp 332 [70], and also used in the North Pond Expedition 336. During Expedition 336, single and multilevel subseafloor borehole observatories for long-term coupled microbiological, biogeochemical, and hydrological experiments were installed at three sites (Holes 395A, U1382A, and U1383C). These operations will lay the foundation for long-term monitoring, experimentation, and observations by subsequent remotely operated vehicle (ROV) or submersible dive expeditions [12]. Clearly, CORKs as subseafloor borehole observatories offer unprecedented opportunities for under water multidisciplinary studies, allow for a comprehensive view of subseafloor microbial life over time and the interaction with the basement hydrogeology and chemistry [44,69,71].

Besides under sea in situ experimentation, state-of-the-art laboratory bioreactors are being designed and used to mimic the natural marine environmental conditions and/or to stimulate the growth of specific microorganisms [72-75]. When considering the deep sea and subsurface conditions, one of the most important parameters to consider is high pressure. Depending on the research purpose and the origin of the samples, different types of high pressure reactors including both high-hydraulic-pressure and high-gas-pressure bioreactors, have been constructed, such as the pressurized chemostat [76,77], and continuous-flow reactor systems [78,79]. For instance, Zhang et al. [80] designed a continuous-flow high-gas-pressure bioreactor to enrich anaerobic methane oxidizers. ANME2 in association with SRB were successfully enriched (Figure 3), and it was demonstrated that methane oxidation rates under $8 \mathrm{MPa}$ were 51 times higher than at atmospheric pressure [79,80]. Parkes et al. [78] constructed a system to perform deep sub-surface sediment sampling and cultivation without depressurization. Zeng et al. [81] isolated the only obligate piezophilic archaeon, extending the present temperature-pressure limitation of organisms from deep-sea hydrothermal chimney sample using high pressure incubator. Imachi et al. [82] have recently utilized a continuous-flow bioreactor to successfully cultivate methanogenic communities from subseafloor sediments. These bioreactors would be extremely useful tools for deep biosphere investigations. 


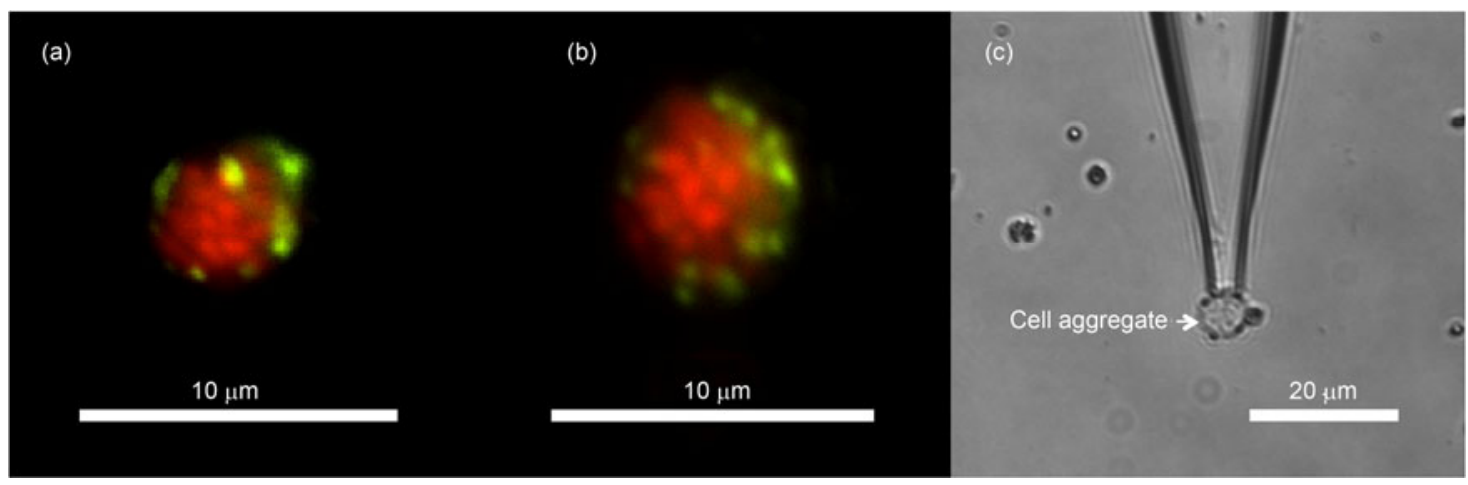

Figure 3 FISH images of ANME-SRB cell aggregates enriched by a continuous-flow high-gas-pressure bioreactor as described in the text. (a) and (b) Epifluorescence micrographs of cell consortia of ANME-2a (red) and DSS (green) cells. ANME cells are surrounded by SRB cells. (c) Photograph showing the capture of the cell aggregate using micromanipulation system. The captured cells could be further processed for genomic analysis. ANME, Anaerobic methanotrophic archaea; SRB, sulfate reducing bacteria; DSS, Desulfosarcina.

\subsection{New tools for molecular microbiology}

The essence for environmental microbiology including marine microbiology is to determine and quantify the geochemical roles of the microorganisms. As the majority of the microorganisms revealed by molecular markers (usually the $16 \mathrm{~S}$ rRNA gene) are uncultivated and have no close culture representative, the physiology and metabolic characteristics of the microbes thus remain unknown, and their possible ecological functions remain elusive. The fast development of molecular techniques has now made it possible to study the whole microbial community as a system. For example, by designing a thermo-coupling cap to allow the growth of a new chimney, and utilization of GeoChipbased, high-throughput metagenomics technology, Wang et al. [27] could reveal the microbial metabolic functions of the communities during the growth of a hydrothermal chimney at the Juan de Fuca Ridge. Metagenome comparison and analysis further revealed that the community in the black chimney from Juan de Fuca enriched in genes for carbon fixation in the CBB cycle and genes for denitrification (Figure 4), showing the major metabolic pathways utilized by the microbial community for $\mathrm{C}$ and $\mathrm{N}$ cycling [67]. We believe that the combined utilization of new molecular techniques such as stale isotope probing [83], single cell separation and sequencing (Figure 3, [84]), isotope analysis of single cells (FISH-SIMS) [53,85], and next generation "omics" approaches such as metagenomics, metatranscriptomics, metaproteomics, metametabolics [86-88] will provide an

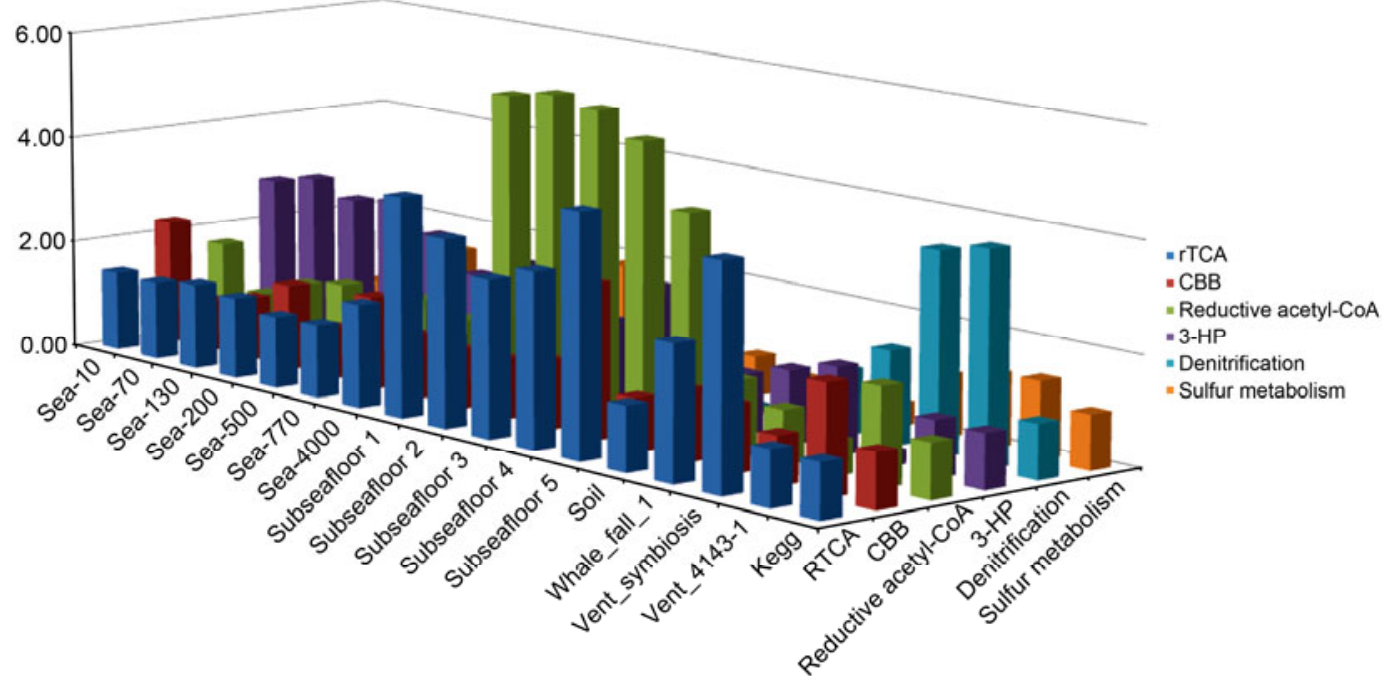

Figure 4 Comparison of enrichment for genes of reductive carboxylate cycle, CBB cycle, reductive acetyl-CoA pathway, 3-HP pathway, denitrification, sufur metabolism and chemotaxis in various environmental samples. Odds ratio is used as the relative risk of observing a given group in the sample relative to the comparison dataset (KEGG). It is calculated by $(A / B) /(C / D)$ where $A$ is the number of hits to a given gene in the microbiome, $B$ is the number of hits to all other annotated gene in the microbiome, $C$ is the number of hits to a given gene in the KEGG dataset, and $D$ is the number of hits to all other genes in the KEGG dataset. Subseafloor: Peru Margin subseafloor biosphere project; soil: Alaskan Soil; sea-10 to sea-4000: sea water of Hawaii Ocean Time-series (HOT) station;Vent_4143-1: Hydrothermal vent chimney sample from Juan de Fuca; Vent_symbiosis: A. pompejana episymbiont metagenome; KEGG: the odd rate of KEGG database. All the reference metagenome data are download from NCBI and treated with the same methods and parameters. 
unprecedented chance to look into the diversity, activity, and evolution of microbes in the subseafloor.

\section{Future and challenges of deep biosphere investigation}

Deep biosphere investigation has a bright future. With the available (and developing) state-of-the-art tools and technologies both for under water experimentation and molecular microbiology, such as subseafloor real-time observatories, stable isotope tracing and "omics" approaches as stated above, we are now approaching an era to be able to carefully address some key questions in subsurface biosphere. In the newly released 10-year plan for the future of the international ocean drilling program [88], biosphere frontiers is listed as one of its research Themes (THEME 2 - BIOSPHERE FRONTIERS: DEEP LIFE, BIODIVERSITY, AND ENVIRONMENTAL FORCING OF ECOSYSTEMS). Three major questions or challenges, including "What are the Origin, Composition, and Global Significance of Subseafloor Communities?" "What are the Limits of Life in the Subseafloor?" "How Sensitive are Ecosystems and Biodiversity to Environmental Change?", were outlined in this theme. Answering these questions demand interdisciplinary approaches, and scientists are expected to make major advances in the next decade.

We now know that microbes do exist in the subsurface environments, but we still lack information to place firm constraints on estimates of total subseafloor biomass and habitable space on our planet. Subsurface biosphere research needs to emerge from a mainly taxonomic and descriptive stage into quantitative multidisciplinary in-situ experiments, coupling microbiological, hydrological, geochemical and geophysical investigations. Our knowledge on the diversity of who is there in the subsurface environments is increasing rapidly, owing to the fast development of DNA amplification and sequencing techniques. However, with the awareness that more than $99 \%$ of the microorganisms in the environments are not yet cultivated or have close related cultivates, it is becoming a big challenge to link the microbial diversity with the physiology, functioning and biogeochemical roles of the microorganisms. More intriguingly, even where laboratory cultured representatives are available, caution is required in to infer the characteristics of the lab culture to the physiology or geochemical roles of the microbes in nature. Even closely related microbial species or even the same species (as basically classified by 16S rRNA gene identities of more than 97\%) may have significant different physiologies and/or metabolic characteristics, it would be more crucial to understand or define the "Geomicrobial Functional Groups" in the environments [89]. Novel experimental approaches using in situ experiments such as FLOCS like systems describe above, and enrichment experiment using stable isotope labeled elements would be powerful to directly link the microbial identity with its physiology and metabolic functioning. However, exactly how to couple small-scale studies of subseafloor microbiology with large-scale biogeochemistry remains challenging. In situ real-time observatories coupling multiple disciplinary hydrological, geochemical, geophysical, microbiological experiments would provide a solution and guide the shore-based single species focused biological experimentation into a field based, quantitative investigation of subsea floor microbial communities.

We thank all the participants of North Pond expedition 336 for a successful cruise supported by IODP. Thanks to Prof. P X Wang from Tongji University for his kind comments and suggestions for the manuscript. This work was supported by the National Basic Research Program of China (2011CB808800), the National Natural Science Foundation of China (40830213), IODP-China, and grants from the State Key Laboratory of Ocean Engineering in China (GKZD010053-1, GKZD010056-5). BNO acknowledges financial support by the Danish National Research Foundation and the Max Planck Society. BNO and KJE are partially supported by the National Science Foundation Center for Dark Energy Biosphere Investigations (C-DEBI, funded by OCE-0939564). This is C-DEBI contribution \#135.

1 ZoBell C E, Anderson Q A. Vertical distribution of bacteria in marine sediments. Am Assoc Pet Geol Bull, 1936, 20: 258-269

2 ZoBell C E, Morita R Y. Barophilic bacteria in some deep sea sediments. J Bacteriol, 1957, 73: 563-568

3 ZoBell C E. Studies on the bacterial flora of marine bottom sediments. J Sediment Res A Sediment Petrol Process, 1938, 8: 10-18

4 Corliss J B, Dymond J, Gordon L I, et al. Submarine thermal sprirngs on the Galapagos rift. Science, 1979, 203: 1073-1083

5 Parkes R J, Cragg B A, Bale S J, et al. Deep bacterial biosphere in Pacific Ocean sediments. Nature, 1994, 371: 410-413

6 Whitman W B, Coleman D C, Wiebe W J. Prokaryotes: The unseen majority. Proc Natl Acad Sci USA, 1998, 95: 6578-6583

7 Lipp J S, Morono Y, Inagaki F, et al. Significant contribution of Archaea to extant biomass in marine subsurface sediments. Nature, 2008, 454: 991-994

8 Edwards K J, Bach W, McCollom T M. Geomicrobiology in oceanography: microbe-mineral interactions at and below the seafloor. Trends Microbiol, 2005, 13: 449-459

9 D'Hondt S L, Jorgensen B B, Miller D J, et al. Proc. ODP Init. Repts. 201: College Station, TX (Ocean Drilling Program). 2003

10 Expedition 331 Scientists. Deep hot biosphere. IODP Prel Rept, 2010, 331. doi: 10.2204/iodp.pr.331.2010

11 Expedition 329 Scientists. South Pacific Gyre subseafloor life. IODP Prel Rept, 329. 2011, doi: 10.2204/iodp.pr.329.2011

12 Expedition 336 Scientists. Mid-Atlantic Ridge microbiology: Initiation of long-term coupled microbiological, geochemical, and hydrological experimentation within the seafloor at North Pond, western flank of the Mid-Atlantic Ridge. IODP Prel Rept, 336. 2011, doi: 10.2204/iodp.pr.336.2011

13 Orcutt B N, Sylvan J B, Knab N J, et al. Microbial ecology of the dark ocean above, at and below the seafloor. Microbiol Mol Biol Rev, 2011, 75: 361-422

14 Edwards K J, Wheat C G, Sylvan J B. Under the sea: Microbial life in volcanic oceanic crust. Nat Rev Microbiol, 2011, 9: 703-712

15 Schrenk M O, Huber J A, Edwards K J. Microbial provinces in the subseafloor. Oceanography, 2009, 2: 85-110

16 Fang J S, Zhang L. Exploring the deep biosphere. Sci China Earth Sci, 2011, 54: 157-165

17 Fry J C, Parkes R J, Cragg B A, et al. Prokaryotic biodiversity and activity in the deep subseafloor biosphere. FEMS Microbiol Ecol, 
2008, 66: 181-196

18 Santelli C M, Edgcomb V P, Bach W, et al. The diversity and abundance of bacteria inhabiting seafloor lavas positively correlate with rock alteration. Environ Microbiol, 2009, 11: 86-98

19 Johnson H P, Priuis M J. Fluxes of fluid and heat from the oceanic crustal resevoir. Earth Planet Sci Lett, 2003, 216: 565-574

20 Fisher A T. Permeability within basaltic oceanic crust. Geol Rev, 1998, 36: 143-182

21 Wheat C G, McManus J, Mottl M J, et al. Oceanic phosphorous imbalance: Magnitude of the mid-ocean ridge flank hydrothermal sink. Geophys Res Lett, 2003, 30: 1895

22 D'Hondt S L, Spivack A J, Pockalnya R, et al. Subseafloor sedimentary life in the South Pacific gyre. Proc Natl Acad Sci USA, 2009, 106: 11651-11656

23 Pollack H N, Hurter S J, Johnson J R. Heat flow from the Earth's interior: Analysis of the global data set. Rev Geophys, 1993, 31: 267280

24 Detrick R S. Portrait of a magma chamber. Nature, 2000, 406: 578-579

25 Fisk M R, Giovannoni S J, Thoreth I H. Alteration of oceanic volcanic glass: Textural evidence of microbial activity. Science, 1998, 281: 978-980

26 Reysenbach A L, Banta A B, Boone D R, et al. Microbial essentials at hydrothermal vents. Nature, 2000, 404: 835

27 Wang F P, Zhou H Y, Meng J, et al. GeoChip-based analysis of metabolic diversity of microbial communities at the Juan de Fuca Ridge hydrothermal vent. Proc Natl Acad Sci USA, 2009, 106: 4840

28 Huber J A, Butterfield D A, Baross J A. Temporal changes in archaeal diversity and chemistry in a mid-ocean ridge subseafloor habitat. Appl Environ Microbiol, 2002, 68: 1585-1594

29 Page A, Tivey M K, Stakes D S, et al. Temporal and spatial archaeal colonization of hydrothermal vent deposits. Environ Microbiol, 2008, 10: 874-884

30 Flores G E, Campbell J H, Kirshtein J D, et al. Microbial community structure of hydrothermal deposits from geochemically different vent fields along the Mid-Atlantic Ridge. Environ Microbiol, 2011, 13: 2158-2171

31 Deming J W, Baross J A. Deep-sea smokers: Windows to a subsurface biosphere? Geochim Cosmochim Acta, 1993, 57: 3219-3230

32 Kelley D S, Baross J A, Delaney J R. Volcanoes, fluids, and life at mid-ocean ridge spreading centers. Annu Rev Earth Planet Sci, 2002, 30: $385-491$

33 Takai K, Gamo T, Tsunogai U, et al. Geochemical and microbiological evidence for a hydrogen-based, hyperthermophilic subsurface lithoautotrophic microbial ecosystem (HyperSLiME) beneath an active deep-sea hydrothermal field. Extremophiles, 2004, 8: 269-282

34 Cowen J. Fluids from aging ocean crust that support microbial life. Science, 2003, 299: 120-123

35 Embley R W, Hobart M A, Anderson R N, et al. Anomalous heat flow in the Northwest Atlantic: A case for continued hydrothermal circulation in 80-M.Y. Crust. J Geophys Res, 1983, 88: 1067-1074

36 Moyer C L, Tiedje J M, Dobbs F C, et al. Diversity of deep-sea hydrothermal vent Archaea from Loihi Seamount, Hawaii. Deep Sea Res Part II, 1998, 45: 303-317

37 Kelley D S, Karson J A, Blackman D K, et al. An off-axis hydrothermal vent field near the Mid-Atlantic Ridge at $30^{\circ} \mathrm{N}$. Nature, 2001, 412: 145

38 Kelley D S. A serpentinite-hosted ecosystem: The lost city hydrothermal field. Science, 2005, 307: 1428-1434

39 Wheat C G, Elderfield H, Mottl M J, et al. Chemical composition of basement fluids within an oceanic ridge flank: Implications for along-strike and across-strike hydrothermal circulation. J Geophys Res, 2000, 105: 13437-13447

40 Bach W, Edwards K J. Iron and sulfide oxidation within the basaltic ocean crust: Implications for chemolithoautotrophic microbial biomass production. Geochim Cosmochim Acta, 2003, 67: 3871-3887

41 Furnes H, Staudigel H, Thorseth I H, et al. Bioalteration of basaltic glass in the oceanic crust. Geochem Geophys Geosys, 2001, 2: 1049

42 Cande S C, Kent D V. Revised calibration of the geomagnetic polarity timescale for the Late Cretaceous and Cenozoic. J Geophys Res, 1995, 100: 6093-6095

43 Shipboard Scientific Party. Juan de Fuca hydrogeology: The hydrogeologic architecture of basaltic oceanic crust: compartmentalization, anisotropy, microbiology, and crustal-scale properties on the eastern flank of Juan de Fuca Ridge, eastern Pacific Ocean. IODP Prel Rept, 301. 2004, doi: 10.2204/iodp.pr.301.2004

44 Expedition 327 Scientists. Juan de Fuca Ridge-flank hydrogeology: The hydrogeologic architecture of basaltic oceanic crust: Compartmentalization, anisotropy, microbiology, and crustal-scale properties on the eastern flank of Juan de Fuca Ridge, eastern Pacific Ocean. IODP Prel Rept, 327. 2010, doi: 10.2204/iodp.pr.327.2010.

45 Edwards K J, Fisher A T, Wheat C G. The deep subsurface biosphere in igneous ocean crust: Frontier habitats for microbiological exploration. Front Microbiol, 2012, 3: 8

46 McCollom T M. Geochemical constraints on primary productivity in submarine hydrothermal vent plumes. Deep Sea Res Part I, 2000, 47: 85-101

47 Lomstein B A, Langerhuus A T, D'Hondt S, et al. Endospore abundance, microbial growth and necromass turnover in deep sub-seafloor sediment. Nature, 2012, 484: 101-104

48 Nauhaus K, Boetius A, Krüger M, et al. In vitro demonstration of anaerobic oxidation of methane coupled to sulphate reduction in sediment from a marine gas hydrate area. Environ Microbiol, 2002, 4: 296-305

49 Nauhaus K, Treude T, Boetius A, et al. Environmental regulation of the anaerobic oxidation of methane: A comparison of ANME-I and ANME-II communities. Environ Microbiol, 2005, 7: 98-106

50 Knittel K, Boetius A. Anaerobic oxidation of methane: Progress with an unknown process. Annu Rev Microbiol, 2009, 63: 311-334

51 House C H, Orphan V J, Turk K A, et al. Extensive carbon isotopic heterogeneity among methane seep microbiota. Environ Microbiol, 2009, 11: 2207-2215

52 Dekas A E, Poretsky R S, Orphan V J. Deep-sea archaea fix and share nitrogen in methane-consuming microbial consortia. Science, 2009, 326: 422-426

53 Beal E J, House C H, Orphan V J. Manganese- and iron-dependent marine methane oxidation. Science, 2009, 325: 184-187

54 Biddle J F, Lipp J S, Lever M A, et al. Heterotrophic archaea dominate sedimentary subsurface ecosystems off Peru. Proc Natl Acad Sci USA, 2006, 103: 3846-3851

55 Inagaki F, Nunoura T, Nakagawa S, et al. Biogeographical distribution and diversity of microbes in methane hydrate-bearing deep marine sediments on the Pacific Ocean Margin. Proc Natl Acad Sci USA, 2006, 103: 2815-2820

56 Meng J, Wang F P, Wang F, et al. An uncultivated crenarchaeota contains functional bacteriochlorophyll a synthase. ISME J, 2009, 3: 106-116

57 Chapelle F H, O’Neill K, Bradley P M, et al. A hydrogen-based subsurface microbial community dominated by methanogens. Nature, 2002, 415: 312-315

58 Mason O U, Di Meo-Savoie C A, Van Nostrand J D, et al. Prokaryotic diversity, distribution, and insights into their role in biogeochemical cycling in marine basalts. ISME J, 2009, 3: 231-242

59 Santelli C M, Orcutt B N, Banning E, et al. Abundance and diversity of microbial life in ocean crust. Nature, 2008, 453: 653-657

60 Orcutt B N, Bach W, Becker K, et al. Colonization of subsurface microbial observatories deployed in young ocean crust. ISME J, 2010, 5: 692-703

61 Lysnes K, Thorseth I H, Steinsbu B O, et al. Microbial community diversity in seafloor basalt from the Arctic spreading ridges. FEMS Microbiol Ecol, 2004, 50: 213-230

62 Emerson D, Rentz J A, Lilburn T G, et al. A novel lineage of proteobacteria involved in formation of marine Fe-oxidizing microbial mat communities. PLoS one, 2007, 2: e667

63 Expedition 330 Scientists. Louisville Seamount Trail: Implications for geodynamic mantle flow models and the geochemical evolution of primary hotspots. IODP Prel Rept, 330. 2011, doi: 10.2204/iodp.pr. 330.2011 
64 Einen J, Thorseth I H, Ovreas L. Enumeration of archaea and bacteria in seafloor basalt using real-time quantitative PCR and fluorescence microscopy. FEMS Microbiol Lett, 2008, 282: 182-187

65 Auguet J C, Barberan A, Casamayor E O. Global ecological patterns in uncultured Archaea. ISME J, 2009, 4: 182-190

66 Takai K, Nakamura K. Archaeal diversity and community development in deep-sea hydrothermal vents. Curr Opin Microbiol, 2011, 14: 282-291

67 Xie W, Wang F P, Guo L, et al. Comparative metagenomics of microbial communities inhabiting deep-sea hydrothermal vent chimneys with contrasting chemistries. ISME J, 2011, 5: 414

68 Davis E E, Becker K, Pettigrew T L, et al. Proc. ODP Init. Repts. 139: College Station, TX (Ocean Drilling Program). 1992

69 Fisher A T, Wheat C G, Becker K, et al. Scientific and technical design and deployment of longterm, subseafloor observatories for hydrogeologic and related experiments, IODP Expedition 301, eastern flank of Juan de Fuca Ridge. 301: College Station, TX Integrated Ocean Drilling Program Management International, Inc. 2005

70 Expedition 332 Scientists. NanTroSEIZE Stage 2: Riserless observatory. IODP Prel Rept, 332. 2011, doi: 10.2204/iodp.pr.332.2011

71 State Key Laboratory of Marine Geology. Under Water Observatories: The Combination of Science and Technology (in Chinese). Shanghai: Tongji University Press, 2011

72 Girguis P R, Cozen A E, DeLong E F. dynamics of anaerobic methaneoxidizing archaea and sulfate-reducing bacteria in a continuous-clow bioreactor. Appl Environ Microbiol, 2005, 71: 3725-3733

73 Deusner C, Meyer V, Ferdelman T G. High-pressure systems for gas-phase free continuous incubation of enriched marine microbial communities performing anaerobic oxidation of methane. Biosens Bioelectron, 2009, 105: 524-533

74 Jagersma G C, Meulepas R J W, Heikamp J I, et al. Microbial diversity and community structure of a highly active anaerobic methaneoxidizing sulfate-reducing enrichment. Environ Microbiol, 2009, 11: 3223-3232

75 Zhang Y, Arends J B A, Van de Wiele T, et al. Bioreactor technology in marine microbiology: From design to future application. Biotechnol Adv, 2011, 29: 312-321

76 Grossart H P, Gust G. Hydrostatic pressure affects physiology and community structure of marine bacteria during settling to $4000 \mathrm{~m}$ : An experimental approach. Mar Ecol Prog Ser, 2009, 390: 97-104

77 Jannasch H W, Wirsen C O, Doherty K W. A pressurized chemostat for the study of marine barophilic and oligotrophic bacteria. Appl Environ Microbiol, 1996, 62: 1593

78 Parkes R J, Sellek G, Webster G, et al. Culturable prokaryotic diversity of deep, gas hydrate sediments: First use of a continuous highpressure, anaerobic, enrichment and isolation system for subseafloor sediments (DeepIsoBUG). Environ Microbiol, 2009, 11: 3140-3153

79 Zhang Y, Henriet J P, Bursens J, et al. Stimulation of in vitro anaerobic oxidation of methane rate in a continuous high-pressure bioreactor. Bioresour Technol, 2010, 101: 3132-3138

80 Zhang Y, Maignien L, Zhao X X, et al. Enrichment of a microbial community performing anaerobic oxidation of methane in a continuous high-pressure bioreactor. BMC Microbiol, 2011, 11: 137

81 Zeng X, Birrien J L, Fouquet Y, et al. Pyrococcus CH1, an obligate piezophilic hyperthermophile: Extending the upper pressure-temperature limits for life. ISME J, 2009, 3: 873-876

82 Imachi H, Aoi K, Tasumi E, et al. Cultivation of methanogenic community from subseafloor sediments using a continuous-flow bioreactor. ISME J, 2011, 5: 1913-1925

83 Takano Y, Chikaraishi Y, Ogawa N O, et al. Sedimentary membrane lipids recycled by deep-sea benthic archaea. Nat Geosci, 2010, 3: 858-861

84 Lasken R S. Single-cell genomic sequencing using multiple displacement amplification. Curr Opin Microbiol, 2007, 10: 510-516

85 Behrens S, Loesekann T, Pett-Ridge J, et al. Linking microbial phylogeny to metabolic activity at the single-cell level by using enhanced element labeling-catalyzed reporter deposition fluorescence in situ hybridization (EL-FISH) and NanoSIMS. Appl Environ Microbiol, 2008, 74: 3143-3150

86 Nunoura T, Takaki Y, Kakuta J, et al. Insights into the evolution of Archaea and eukaryotic protein modifier systems revealed by the genome of a novel archaeal group. Nucleic Acids Res, 2011, 39: 32043223

87 Hallam S J, Mincer T J, Schleper C, et al. Pathways of carbon assimilation and ammonia oxidation suggested by environmental genomic analyses of marine Crenarchaeota. PLoS Biol, 2006, 4: 520-536

88 Illuminating earth through subseafloor sampling, observation, and experimentation: The international ocean discovery program, science plan for 2013-2023. Washington DC: IWG Supporting Office, 2010

89 Xie S, Yang H, Luo G, et al. Geomicrobial functional groups: A window on the interaction between life and environments. Chin Sci Bull, 2012, 57: 2-19

Open Access This article is distributed under the terms of the Creative Commons Attribution License which permits any use, distribution, and reproduction in any medium, provided the original author(s) and source are credited. 